\title{
The Alacrity of Preschool Education Teachers to Work with Children in Inclusive Groups
}

\author{
Diatlenko N. ${ }^{1, *}$, Goncharenko A. ${ }^{1}$, Smolnykova H ${ }^{1}$, Sabol D. ${ }^{2}$, Kocherga O. ${ }^{1, *}$ \\ ${ }^{1}$ Department of the Methodology and Psychology of Preschool Education, Borys Grinchenko Kyiv University Institute of Teacher \\ Education, Street Bulvarno-Kudryavska, Ukraine \\ ${ }^{2}$ Borys Grinchenko Kyiv University, Institute of Teacher Education, Street Bulvarno-Kudryavska, Ukraine
}

Received September 25, 2020; Revised November 7, 2020; Accepted November 23, 2020

\section{Cite This Paper in the following Citation Styles}

(a): [1] Diatlenko N., Goncharenko A., Smolnykova H, Sabol D., Kocherga O. , "The Alacrity of Preschool Education Teachers to Work with Children in Inclusive Groups," Universal Journal of Educational Research, Vol. 8, No. 12A, pp. 7710 - 7722, 2020. DOI: 10.13189/ujer.2020.082558.

(b): Diatlenko N., Goncharenko A., Smolnykova H, Sabol D., Kocherga O. (2020). The Alacrity of Preschool Education Teachers to Work with Children in Inclusive Groups. Universal Journal of Educational Research, 8(12A), 7710 - 7722. DOI: 10.13189/ujer.2020.082558.

Copyright $\bigcirc 2020$ by authors, all rights reserved. Authors agree that this article remains permanently open access under the terms of the Creative Commons Attribution License 4.0 International License

\begin{abstract}
The purpose of the study was to investigate the readiness of educators of preschool education institutions in Kyiv to work in inclusive classrooms. The parameters of the research are taken into accounts, such as attitude to the idea of inclusion, possession of the necessary arsenal of pedagogical practices, understanding of barriers and ways to overcome them on the way to the organization of inclusive education. The results of the study showed that a significant number of educators have a negative attitude to the idea of inclusion, believing that children should study in special groups or in special institutions (but not boarding schools). The question of the determinants of educators' attitudes towards inclusive education, which are related to their work experience, seems to be important. The results showed that most respondents have 20-30 years of experience working with preschoolers in general developmental groups. The picture of educators of inclusive groups differs sharply: among them, $42 \%$ of people have work experience of up to 5 years. This trend may speak in favour of the ability to learn, interest in changes in education, a sense of potential and professional resources to work in more difficult conditions. Educators with 30 years of experience or more are wary of this choice. Only $8.9 \%$ of them found their interest in working with children with special educational needs.
\end{abstract}

Keywords Barrier, Inclusion, Inclusive Education, Children with Special Educational Needs, Participation

\section{Introduction}

In the process of integration into the European community, Ukraine has focused on educational reforms, in particular, the creation of conditions for the introduction of inclusive education in educational institutions [1].

The Convention on the Rights of Persons with Disabilities and its Optional Protocol (2009), ratified by Ukraine, have made radical changes in their treatment of people with special needs. This first comprehensive treaty of the 21 st century has changed the paradigm of attitudes and approaches to the problems of persons with disabilities. The Convention and the Optional Protocol became part of the Ukrainian legislation and initiated changes in education, intensified the activities of public organizations [2].

The innovative Law of Ukraine "On Education" (2020) was adopted, which opened a wide field for the introduction of inclusion in the education system. The law provides for equal access to education, regardless of age, sex, race, health, disability, citizenship, nationality, political, religious or other beliefs, skin colour, place of residence, language, origin, social and property status, criminal record, as well as other circumstances and signs. Article 20 states that educational institutions, if necessary, shall form inclusive and/or special groups and classes for the training of persons with special educational needs. If a person with special educational needs or his or her parents 
applies, such a group or class must be formed [3].

Public authorities and local governments form inclusive resource centres to ensure the realization of the right to education and psychological and pedagogical support for children with special educational needs [4].

The Department of Education and Science, Youth and Sports of Kyiv has developed a special comprehensive program for the development of education for the period 2019-2023, where much attention is paid to the implementation and dissemination of the model of inclusive education in educational institutions. The document sets tasks for monitoring the number of children in need of inclusive education, expanding the network of inclusive groups in preschool institutions, in accordance with the needs of city residents, implementing a set of measures for timely preparation of educational institutions for admission to inclusive groups. All this confirms the political attitude of public authorities to changes in the education system in terms of inclusion and access of all children to education [5].

According to 2020, there are more than 14.7 thousand preschool children with special educational needs in the city of Kyiv; the vast majority of them are educated in special groups and institutions, and only a small part (339 people) attends preschool institutions with 120 inclusive groups in their structure. Last year, there were 90 such groups, and they raised about 200 children with special educational needs. There is a tendency to increase the number of inclusive groups and children in them requiring a comprehensive approach to improving the professional competence of educators and, first of all, to find out their readiness and willingness to work in such groups [6].

Despite significant changes in the organization of inclusive education, creating conditions for people with disabilities, opinion polls show that more than half of Ukrainians (54\%) see the existence of a real problem in Ukraine restricting the rights of people with disabilities and this situation needs immediate change. The European Research Association has concluded that the main initiators of inclusive education for children with disabilities based on the principles of equal opportunities are parents and NGOs, while educational institutions do not demonstrate such an attitude [7].

There is a lot of research in the world scientific literature on inclusive education and the readiness of educators/teachers to work in inclusive groups of educational institutions. The presented research reflects the specifics of socio-economic conditions, historical and mental features of the country where it was carried out. Ukraine is only taking the first steps in organizing inclusive education, trying to get rid of the totalitarian past and build its own effective educational model. This requires an in-depth analysis of the approaches, efforts, and results that have been made in this direction in other countries [8].

The study of scientific research makes it possible to identify and analyze the social model of attitudes to disability, which convincingly and diversely considers the problem of a person with special needs in society and overcoming existing barriers. A significant step in the implementation of inclusive education was the acquaintance of the pedagogical community with the ICF - the international classification of functioning, which means focusing not on the diagnosis of the person, but on his ability to develop and actively participate [9].

Ukraine has significant socio-cultural resources for the successful implementation of inclusive learning ideas. However, in real life, there are significant contradictions between the declared ideas and the real state of affairs. One of such contradictions is the discrepancy (inconsistency) between state plans and projects for the development of inclusive education and the willingness of educators/teachers to work in such groups, which requires the latter to understand and accept humanistic ideas of inclusive education, good orientation in the specifics of an inclusive culture and sufficient skills. Inclusive practice.

The first part of our study is devoted to the theoretical analysis of research in different countries that have been done to organize inclusive education, and in particular, in the readiness of teachers to work in inclusive classes/groups. Analyzing the readiness of educators/teachers to work in inclusive classrooms, they focused on the nature of their attitude to the idea of inclusion, their understanding of the barriers that arise along the way and ways to overcome them; idea of owning special pedagogical practices [10].

As part of the study, we were interested in the results of research on the introduction of inclusive education in other countries with more experience than in Ukraine. The research of scientists from different countries was analyzed: Great Britain, Greece, Israel, New Zealand, Germany, the USA, Turkey, which was carried out at different times, starting from the 2000s.

Familiarity with the results of the research has shown that most scholars consider the teacher a determinant in the organization of inclusive education, and his positive attitude to inclusive change, which is the basis of readiness to work in such a class, is recognized as a necessary condition. [11]; Preschool teachers are much more committed to the idea of inclusion than school teachers, who are more focused on the subject and its teaching than on the development of students [12],[13].

The fact that the world community of preschool educators is more loyal to the idea of inclusion can be explained by the specifics of the organization of life in the institution, which allows the use of a wide arsenal of forms and methods of working with children, choosing ways to assess academic achievement, tracking child progress.

The professional activity of a teacher at school is regulated by a number of requirements and rules, among which one of the main ones is the responsibility for the 
quality of education of all children. The presence in the classroom of a child with special educational needs strains and complicates the educational process, requires additional effort and additional resources from the teacher. Those who only have occasional contact with children, such as the school administration, tend to respond positively to the idea of inclusion in most cases [13].

According to researchers, the success of the development of children with special educational needs depends on the attitude of teachers to the integration process, to inclusiveness in it. A positive attitude enhances the child's chances for further integration, to continue classes in another classroom, where inclusion can continue to work successfully. The average efficiency of a child's work in the company of typical peers was determined by the majority of teachers and parents in the range of $70-80 \%$. The authors of the study emphasize the traditional pedagogical expectations: the development of the child's skills to immediately follow the instructions of an adult and answer individual questions, as well as - to fill in workbooks. Unfortunately, such compliance skills are the highest in the minds of teachers, making it difficult for children to integrate into regular classes.

However, the significance and importance of the teacher's perception of the child's integration success contribute to the improvement of the child's behaviour and learning effectiveness. Therefore, the findings of the study contain a clear and unambiguous position of the future: teachers will have to learn to more carefully assess the skills of integrated children in the classroom. Otherwise, there is a risk of depriving children of the opportunity to use previously developed skills.

Studies by Turkish scholars show that inclusive practices are useful for supporting a child's social development, more than half of educators believe that preparation for inclusion promotes student development, but ensuring successful inclusion depends on team training and based on child observations [14].

However, researchers note another pattern: gradually, as the educator/teacher immerses himself in work in an inclusive classroom, masters the ways of organizing the class, changes his attitude to the inclusion of children with special educational needs towards the positive [15],[16].

One of the factors influencing the attitude of teachers to inclusive education is called the nature of the child's disability, i.e. the level of its functionality. Most scientific studies argue that the success of inclusion depends largely on the nature of the disease, the ability to adapt, the adequacy of children's behaviour in general [13],[17],[18].

The point of view of teachers who deny the possibility of successful education of children with complex physical, mental, behavioural disorders, allows such participation only for children with minor developmental disabilities. Teachers are unanimous in their rejection of the idea of including children with severe intellectual and sensory impairments [19].
Some studies done at different times suggest that the main reason for the difficulties of adaptation of individual children to inclusive education should not be considered features of developmental disorders, and the unpreparedness of the education system for the education of such children. There is talk of meeting the individual needs of children, and this is the best way to succeed in an inclusive classroom [16].

This is confirmed by a study of recent years, according to which some teachers do not even try to involve children with special educational needs in academically complex activities from the standpoint of their inability, assuming that they will not cope; however, only a small number of them state that the participation of these children largely depends on the organization of the educational process, adaptations and modifications in the classroom [17].

An important factor that significantly affects the nature of the attitude to the idea of inclusive education is called a weak awareness of the peculiarities of the development of children with special educational needs and pedagogical practices of working with them. Teachers do not have practical skills to adapt and modify programs, do not know how to communicate with children and their parents. They are often busy with things that are not directly related to working with children, and this, in turn, requires energy and effort. Therefore, inclusion is often seen as an additional burden [11].

Teachers have little idea how to include children with special needs in the general educational process and ensure their equal participation with other children. Some of them believe that they should be accompanied by professionals who are well versed in the development of such children and know how to work with them [20], noting that the situation would have been improved significantly if the curriculum and further postgraduate teacher training focused on the practical training of teachers to work in inclusive classrooms [21].

Another study found that more than half of teachers view inclusion as a process in which a child with special educational needs has to adapt to a virtually unchanged environment, i.e. to curriculum, rules, and the main responsibility for meeting the needs of these children should lie with a special teacher [17].

The process of organizing the educational process in an inclusive classroom involves individual lessons; for some of the children their share in the total is quite high. In this regard, educators are concerned about maintaining a balance between inclusion and individualization in order to avoid marginalization on the one hand and to achieve academic success on the other.

The list of barriers to the loyal attitude of teachers to include children with special needs in their classrooms is supplemented by overcrowded classrooms and a large number of children with special needs in one class, lack of support from colleagues, administration, support staff.[13]

A study by Bhutanese scholars identifies playgrounds 
that are unsafe for children with special educational needs, inaccessible toilets, and overcrowded classrooms [22]. Educators feel responsible for meeting the learning and development needs of all children, trying to succeed in the educational process, so they are concerned about developing special programs that can be used for children with special educational needs, training professionals who know such children well and can with the work.

The question of how the inclusion of children with special educational needs can be beneficial or harmful for all children in the class is commonly discussed. A number of studies have shown that such a combination is beneficial for all children in the class and does not lead to any negative consequences. At the same time, the performance of children in a class either increases or has neutral consequences. There are examples of how the behaviour of all children has changed positively after inclusion: they began to help those who need it; more trust and cooperation; improved social skills.

It is called a condition for improving relationships between peers: expanding contacts with children with special educational needs, the opportunity to get to know each other better, the organization of joint activities. There are studies that show the negative impact of children with special educational needs who have emotional and behavioural problems on other children, teachers and the school environment [18].

One study describes specific examples where the behavioural problems of children with special needs negatively affected the general atmosphere and relationships of children in the classroom, and teachers did not know how to overcome such a problem. Teachers faced a problem when the usual strategies for influencing children did not work.

Research on the well-being of teachers working in inclusive classrooms has not gone unnoticed. Studies of stress experience are analyzed, it is concluded that the level of stress is little affected by work in inclusive classes; attention is drawn to the fact that this is prevented by teamwork, school management, development of the school on the basis of inclusive values [23].

Inclusion implies the coherence and partnership of families of children with and without special needs. Teachers work even more enthusiastically when they see support and recognition from families. Most parents are positive about the joint learning of all children, but in some cases, they say they do not want to see their child with special educational needs, fearing depression.

The scientific literature discusses the question of the dependence of the nature of the teacher's attitude to inclusive education, depending on his age and experience of pedagogical work. A study by [19] found that young teachers with little work experience (less than six years) were more inclined to work in an inclusive classroom than teachers with significant work experience [24]. Significantly better results in terms of readiness to work with children in an inclusive classroom are shown by teachers who have at least some previous experience in an inclusive classroom [25].

Thus, the analysis of scientific research on the readiness of preschool teachers to work in inclusive classrooms showed the existence of global trends in this issue, in particular, ambiguous, often wary, and even negative attitude to the organization of inclusive education by teachers and parents; For most participants in the educational process, barriers are overcrowded classrooms, insufficient help from special educators, low level of mastery of special pedagogical practices, difficulties in adapting and modifying educational materials, low level of support from colleagues and parents. Teachers of inclusive classes need constant support and training, which should be practice-oriented.

\section{Materials and Methods}

The study lasted from the first half of 2019 to the first half of 2020, the empirical phase lasted for six months (September 2019 - February 2020) and covered research activities on respondents - educators of municipal preschools in all ten districts of Kyiv.

The study included two main stages: 1st stage theoretical, the purpose of which was to get acquainted with international experience in the organization of inclusive education; Stage 2 - empirical (ascertaining), the purpose of which was to assess the readiness of teachers of preschool education in Kyiv to implement inclusive forms of education in order to identify weaknesses and further develop the necessary strategy to improve their professional competence, which can be implemented within the Institute postgraduate pedagogical education of University named after Borys Hrinchenko in Kyiv. The effectiveness of the approaches used to form the readiness of teachers of preschool education to work in inclusive groups will be reflected in the next scientific article [26].

The study used the methods of structured written survey (questionnaire), research interview and mathematical data processing, which gave the opportunity to see the statistical picture of the studied phenomenon. The optimal combination of methods provided in-depth information on the attitude of preschool teachers to inclusive education in general and assessed the conditions that promote or hinder the emergence of willingness and willingness to work in an inclusive group. This allowed us to analyze not only the external organizational and pedagogical facts but also the internal motivation, attitude, self-esteem, awareness of barriers and resources for working in an inclusive group.

In the process of empirical research, two questionnaires (closed questionnaires) were used, the first of which contained eight questions with 33 possible answers and was offered to educators of preschool institutions working 
in municipal institutions in groups of the general development of children; the second, which contained seven questions with 38 possible answers, was intended for educators of inclusive groups. The difference between the questionnaires was that the latter included questions related to self-assessment of one's own professional experience as an educator of children in an inclusive group [27].

Through questionnaires it was planned to collect information about the place and experience of respondents, attitudes to where children with special educational needs should study, awareness of the importance of inclusion for all children, self-assessment of readiness to work in an inclusive group in general and ability to perform certain components of inclusive education. Assessment of the contributions of various organizations is in preparation for working in an inclusive group and a declaration of their own attitude to such work. Details of the content and objectives of the questionnaire are given in Table 1 [28].

In addition to the questionnaire, a structured in-depth interview method was used for educators working in general development groups and inclusive groups and participating in a previous survey. Respondents were invited to participate in the interview, which showed different attitudes to the idea of inclusion based on the results of the questionnaire. This strategy is explained by the fact that we tried to get a holistic picture of the readiness of different educators, both those who work in inclusive groups and those who work in groups of the general development of children, but at any time can start working in inclusive; both those who are positive about such work and those who today do not accept this version of the educational process.

It was important to understand the internal motivational and external organizational and pedagogical factors that determine the nature of the attitude to inclusive education and affect the level of readiness to work in such groups. The information obtained will be reported to the Department of Education of the city of Kyiv and used to develop the content of training programs for teachers of inclusive groups [29].

The content of the interview and the organization of the procedure focused on modern requirements and approaches to the development of such a research method. The requirements for the procedure were met: the interviews were conducted in the usual conditions for preschool teachers (but in separate rooms); educators from different districts were invited (but all from municipal preschools); to reduce the possible influence of the interviewer's personality on the results, it was carried out by three researchers; the duration of the interview did not exceed the permissible norms; respondents' answers were recorded on a dictaphone.

Table 1. Diagnostic tools (written survey)

\begin{tabular}{|c|c|c|c|}
\hline $\begin{array}{c}\text { The purpose of the } \\
\text { survey }\end{array}$ & Characteristics of questions & Questions & $\begin{array}{c}\text { Questionnaire } \\
\text { number }\end{array}$ \\
\hline \multirow{3}{*}{$\begin{array}{l}\text { Collect statistical } \\
\text { information }\end{array}$} & \multirow{3}{*}{ ascertaining, digital } & Your experience as an educator in PEI & \multirow[b]{2}{*}{ Questionnaire 1} \\
\hline & & $\begin{array}{l}\text { Do you currently work in an inclusive group of a } \\
\text { preschool institution? }\end{array}$ & \\
\hline & & $\begin{array}{c}\text { Your experience as an educator } \\
\text { inclusive group preschool education institutions }\end{array}$ & Questionnaire 2 \\
\hline \multirow{2}{*}{$\begin{array}{c}\text { Determine the } \\
\text { professional self-esteem } \\
\text { and professional } \\
\text { competence of the } \\
\text { teacher }\end{array}$} & \multirow{2}{*}{$\begin{array}{l}\text { ranking from the lowest score } \\
\text { (1) to the highest (5) }\end{array}$} & $\begin{array}{c}\text { Assess your level of readiness to work in an } \\
\text { inclusive institution }\end{array}$ & Questionnaire 1 \\
\hline & & $\begin{array}{l}\text { Assess your readiness to implement certain aspects } \\
\text { of inclusive education }\end{array}$ & Questionnaire 2 \\
\hline \multirow{2}{*}{$\begin{array}{l}\text { Determine the attitude } \\
\text { of teachers to the } \\
\text { problem and readiness } \\
\text { for innovation }\end{array}$} & \multirow{2}{*}{$\begin{array}{l}\text { selective from the offered } \\
\text { variants }\end{array}$} & $\begin{array}{l}\text { Where do you think children with special } \\
\text { educational needs should be educated? }\end{array}$ & \multirow[b]{2}{*}{ Questionnaires 1,2 } \\
\hline & & $\begin{array}{l}\text { Do you think that the presence of children with } \\
\text { special educational needs in the regular group is an } \\
\text { additional educational resource for all children? }\end{array}$ & \\
\hline $\begin{array}{l}\text { Identify difficulties that } \\
\text { level significant } \\
\text { motives }\end{array}$ & $\begin{array}{l}\text { ranking from the lowest score } \\
\text { (1) to the highest (5) }\end{array}$ & $\begin{array}{l}\text { Assess the level of barriers, barriers to the } \\
\text { implementation of inclusive education }\end{array}$ & Questionnaire 1 \\
\hline $\begin{array}{l}\text { Determine the quality } \\
\text { of the information } \\
\text { space }\end{array}$ & $\begin{array}{l}\text { ranking from the lowest score } \\
\text { (1) to the highest (5) }\end{array}$ & $\begin{array}{l}\text { Evaluate the contributions of different organizations } \\
\text { or individuals to familiarizing you with the specifics } \\
\text { of working in an inclusive group }\end{array}$ & Questionnaires 1,2 \\
\hline $\begin{array}{l}\text { Identify the state of } \\
\text { self-determination of } \\
\text { the educator's readiness } \\
\text { to change activities }\end{array}$ & $\begin{array}{l}\text { selective from the offered } \\
\text { variants }\end{array}$ & $\begin{array}{l}\text { Would you like to work in an inclusive group of } \\
\text { preschool education? }\end{array}$ & Questionnaire 1 \\
\hline
\end{tabular}


In the course of the interview, they tried to clarify the information of the respondents about where children with special needs should be educated (the nature of the answer indicated whether the position had changed since the last survey) and why; how the respondent assesses his / her own level of readiness to work in inclusive groups, why; it was suggested to identify barriers and explain exactly how they affect work; what nosology the respondents work with and what difficulties and barriers exist in working with such children [30].

The results of the interviews were analyzed by categories, taking into account the differences: in the attitude of educators to the opportunities for children with special needs to attend different educational institutions; existing barriers to the implementation of inclusive education; readiness of educators to work in inclusive groups with children from 2 to 7 years [31].

For a holistic approach and depth of analysis, reliability of information and understanding of contradictions, 329 women educators (optional) of different ages with different work experience (from 1 year to 30 years and more) working in different preschools in Kyiv were interviewed. Of these, 242 people work in groups of the general development of children (conditionally separated in category VZ) and 87 people who work in inclusive groups (conditionally separated in category VI). Each respondent was assigned a code, depending on the group in which the educator works (educators working in groups of the general development of children (VZ - 242); educators of inclusive groups (VI - 87).

Ahead of a detailed analysis of the written survey, it can be argued that the sample of respondents reflects the general population, i.e. is representative (due to operational validity, relative homogeneity, adequacy); The views expressed by the participants reflect the overall real situation with the readiness to work in inclusive groups of preschool education institutions in Kyiv [32].

The structured interview was attended by 15 educators working in regular and inclusive groups and participated in a preliminary survey, of which three respondents - from category VZ and 12 - from category VI. Respondents were invited to participate in the interview in equal proportions, who showed a positive and negative attitude to the idea of inclusion according to the results of the questionnaire. This strategy is explained by the fact that we tried to make a holistic picture of the readiness of different educators, both those who work in inclusive groups and those who work in ordinary ones, but can start working in inclusive groups at any time; both those who today believe that children should be brought up in inclusive groups and those who oppose it.

\section{Results and Discussion}

A structured questionnaire of preschool teachers attempted to reveal their attitudes towards inclusive education in general and to assess the conditions that promote or hinder the emergence of willingness and willingness to work in an inclusive group.[33]

The question of the determinants of educators' attitudes towards inclusive education, which are related to their work experience, seems to be important. The results showed that most respondents have 20-30 years of experience working with preschoolers in general developmental groups. The picture of educators of inclusive groups differs sharply: among them, $42 \%$ of people have work experience of up to 5 years. This trend may speak in favour of the ability to learn, interest in changes in education, a sense of potential and professional resources to work in more difficult conditions. Educators with 30 years of experience or more are wary of this choice. Only $8.9 \%$ of them found their interest in working with children with special educational needs.

One of the reasons for anxiety and negative attitude towards work in inclusive groups is the feeling of insufficient preparation for such work. Those who have made their choice in favour of inclusive education are optimistic. Self-esteem is defined by most of them as average and higher, while educators who work in groups of the general development of children assess themselves less optimistically: self-esteem is average and lower.

The answers of educators also differ significantly regarding the location of children with special educational needs. The respondents had inconsistencies, differences, and even polarity in relation to the creation of inclusive groups. Even among those who already work in inclusive groups, only about half of the respondents have a positive attitude to the education of children in inclusive groups of children with disabilities (46.26\%). Among educators of general development groups, $41.32 \%$ prefer to limit children's education to special institutions or special groups of general development institutions. Educators working in groups of the general development of children adhere to the extreme degree of choosing the place of stay of a child with special educational needs in closed institutions (special boarding schools) - 6.19\%: half of them believe that there is no use in staying in a group with children with there are no special needs and that the presence of such children in the regular group cannot become an additional educational resource $(52.47 \%)$.

Those who have tried themselves as educators of an inclusive group have a different opinion. $76.11 \%$ of them are convinced that the presence of such children is a significant and powerful resource for the whole community, which can and should be used. And only $1.49 \%$ of such respondents believe that a child's stay in special boarding schools is possible.

All teachers are aware that working in inclusive groups requires special training, creating conditions, penetration and understanding of the situation. Given that the idea of inclusive education is only gaining ground in Kyiv, 
educators are aware that risks are inevitable and sometimes seem insurmountable. Among others, we identified the most visible and common risks and asked respondents to assess them.[34]

Equally important difficulties, which are taken into account by educators of both category VZ (66.11\%) and category VI $(34.32 \%)$ - the size of groups where the number of children significantly exceeds the norm. It is worth noting that overcrowded groups in preschools in Kyiv are a widespread and long-standing phenomenon.

Every second educator who does not work in an inclusive group complains about the lack of specialists to support the development of children with special needs. Such teachers identify the inclusive group with the specialized groups of PEI. For example, in speech therapy, where a teacher-speech therapist, qualified in accordance with the established nosology of students, plans, organizes, structures and systematically implements the content of pedagogical influence, and the educator continues to implement individual tasks during the day in various fragments of the child's life. In this part of educators, there is a warning that in the absence of a suitable specialist, they will not cope and will not be able to meet the needs of the child. Respondents openly admit that they still lack knowledge, fragmentary understanding of nosography, and lack of practical experience.

Teachers of both categories showed a critical view of their own level of awareness about working in inclusive groups: this is the middle level.

All teachers are aware that each individual child needs differently from traditional approaches, methods, ways of its socialization.

More than half of the educators of category VI accept the idea of inclusive education, understand the need to create inclusive groups, welcome their annual increase in the space of the capital's preschool education. And only one in three VZ educators shares these views.

Educators working in inclusive groups rely on social acceptance and approval of their choices. However, they do not believe that the choice of place of work or social status is significantly/decisively influenced by relationships with colleagues. Unlike their colleagues, educators of category VI in the first place bring the importance of relationships in the team. We assume that they understood the specifics of working in inclusive groups, among which one of the main ones is the ability to work in a team, provide support to others and feel it themselves, together with discuss complex issues of education of individual children.

All educators take into account the level of financial remuneration, considering it as an essential sign of motivation to work not only in the inclusive group but also in the group of the general development of children. This feature is twice as often mentioned by educators of the VZ group, proving that the salary is too low.

Analyzing the attitude of teachers to work in inclusive groups, we see this as a prerequisite for conscious choice in favour of such groups, a sign of readiness to accept the idea of inclusive education. However, the survey shows pessimistic views of VZ respondents, unwillingness to change the usual way of working and to acquire the role of the educator of an inclusive group. Low wages do not meet the level of expectations, do not cover the costs, complexity and intensity of work in either general or inclusive groups. Teachers are aware that working in a group, where a child with special educational needs is among others, is extremely responsible and intense, requires an understanding of the general behavioural picture and requires a wide arsenal of pedagogical tools. This is the risk that $83.88 \%$ of surveyed teachers in Kyiv blocked the desire to work in groups with inclusive education and only $16.11 \%$ of respondents expressed a willingness to be an educator of an inclusive group.

Among other reasons, we consider how educational structures acquaint teachers with the peculiarities of working in an inclusive group, help them to perceive and accept the introduction of this practice common to the civilized world, acquire practical skills, create a barrier-free environment and more. Such a mission in our society relies on multilevel structures. We tracked the vision of this process and the result according to the answers of the respondents.

The contribution of refresher courses was highly appreciated by category VI educators: every third answer. Educators working in groups of the general development of children (category VZ) spoke a little differently about such courses - the benefit was indicated in $43.38 \%$, but the Institute of Postgraduate Pedagogical Education is not in the first place in terms of importance.

District methodological associations, heads of preschool education institutions, educators-methodologists, psychologists are more focused on the needs of educators of groups of the general development of children, as evidenced by every second respondent. However, these officials and associations are not carriers of primary information or do not go into detail with practical comments. A slightly different picture emerged when summarizing the results of the survey of educators working in inclusive groups: twice as often (compared to the VZ category) they can count on consultation, support, information, clarification from the head and other teachers and psychologists of preschool education. But almost equally for categories VZ and VI, there is a lack of practical training, where you can test your effective and ineffective behavioural responses, analyze settings, develop skills in real-time and change strategies.

The activity or availability of educational projects and the participation of educators in them seems to be too low. In the most definite position (5 points) in favour of educational projects responded educators of groups $\mathrm{VZ}$ (12.39\%) and educators of groups VI (17.91\%). 
Given these results of the survey, we set a goal to find out what is the professional self-esteem of educators who already work in inclusive groups in Kyiv. It seems important to understand the individual needs and opportunities of children, the ability to work in harmony with children, other teachers, parents, to build individual educational trajectories. Every third educators rated their level as sufficient or high in terms of joint work with the educator's assistant and the successful organization of interaction between children. And the ability to establish a fruitful and friendly interaction of the teacher with parents is well enough witnessed by $25.37 \%$ of educators. $41.79 \%$ of respondents do it very well. It can be hoped that such self-assessment is a confirmation of the commonality of the two social institutions in terms of the conceptual vision of the problem and the development of tactics for the closest search. Obviously, the problem of a child with special educational needs joining the group was not too difficult or painfully acute, and the preschooler found his place among his peers. It is this circumstance that could be decisive in the formation of a favourable relationship between family and caregivers, which will project cooperation for the future.

Confidence in the work of an inclusive group educator is added by his involvement in the orderliness of the educational process and trust in the organization of children's lives. Participation in the development of an individual educational program is recognized as important. The educator's complicity in this process is a recognition of his professionalism, ability to observe and understand the needs and capabilities of the child. Of the respondents, only a third of teachers $(34.32 \%)$ confirm that they are equal participants in the process of developing an individual educational program. This figure seems quite low, given the role of the educator in its implementation.

Thus, the results of the survey allow us to draw conclusions:

- Most educators of children of general development believe that children with special educational needs should study in special groups or in special institutions. This attitude can be explained by the state's position over the decades and the result of many years of experience, reinforced by basic education, a large number of like-minded people in the field of preschool education, exaggerated caution about change; established norms and rules of organization of preschool education;

- divergence or even opposite views of both categories of educators on their professional training suggest a superficial awareness of $\mathrm{VZ}$ representatives in the specifics of an inclusive culture, the processes of transformation of self-education and the crucial role of partnership with children and their parents

- educators whose work experience does not exceed five years, understand the creation of inclusive groups and opportunities to work with children with
SEN, seeing it as an educational reserve and personal resources to replenish the arsenal of pedagogical tools, building individual educational trajectories.

QSR NVivo9 software (QSR International Pty, Ltd., Victoria, Australia) was used to analyze the interview data. The second part of our study analyzed the results of an in-depth interview conducted with educators working in general development groups and in inclusive groups. Let's take a closer look at the data obtained during the interview.

When asked where children with special educational needs should be educated, most respondents agree that these should be inclusive groups in preschools of general type, but provided that such groups are provided by highly qualified specialists (assistants, speech pathologists, psychologists) (VI 2; VI 3; VI 5; VI 6; VI 8; VZ-64; VZ-88; VZ-72). When asked why they think so, it was said about the best opportunities for adaptation to life in society, about opportunities for the education of humane feelings, about expanding the zone of independence. Here are some examples of statements of educators:

"I can't imagine working outside of inclusion because it gives me inspiration and confidence that I'm really helping children adapt to this difficult life. But the most important thing in my work is that I see gratitude in the eyes of children and they gladly go to the group, play, practice, walk on the street and show their achievements, and this is the most important thing for me" (VI-7).

"I see how easily and simply these children get used to the conditions of the institution, and all other children learn to help and sympathize with those who need it" (VZ-88)

"It seems that the whole world will be better, and the parents of our children also begin to perceive the world differently" (VZ-72).

However, there were other answers. One respondent categorically stated: "Children with special needs should be educated in specialized institutions. And in no case in preschool institutions of the general type" (VI 4).

"I believe that a special preschool is the best option for children with special educational needs, there is a proper number of specialists and employees of the institution; and also, there is various equipment, developmental material. In such conditions, the child will develop better, will be paid more attention and will show better learning outcomes” (VI-12).

"No one will benefit from the joint stay of children in one group. We are accustomed to such children having to be brought up in special groups or institutions. Other children begin to follow their example, and then it is difficult to relearn" (VZ-38).

The results of the interview on where exactly children 
with special educational needs should be educated fully confirmed the data obtained in the first stage of the study; all respondents were true to their choices made during the survey.

The majority of respondents stated that they consider the presence of children with special needs in the general development group as an additional educational resource for all children; to the question why they think so, the following answers were received:

- "In communication with children with special needs, preschoolers learn to be compassionate and considerate of others" (VI 1).

- "Children can enrich their sensory sphere, show emotions, a positive attitude towards a child with special needs. And this will happen in the ordinary life of the group when you need to help a particular boy or girl to show certain emotions. Emotions can be positive or negative, but everyday children practice real positive actions. And they do not need didactic pictures with invented moral situations" (VI 2).

- "Children with special needs help adults to awaken positive feelings in all the pupils of the group. After all, conditions are created when it is necessary to help the weaker, to show care, pity, to try to tell him about what he does not know" (VI 5).

- "It is in inclusive groups that different forms of children's communication are envisaged, and this is positive" (VI 8).

- "Usually children with special needs, before coming to preschool, are limited to communication with relatives in the family circle, less often with children with whom they play on the playground. Therefore, they are always interested in information that can be shared by peers. Similarly, ordinary children need to communicate with children with special needs in a preschool setting. Often parents do not notice children with special needs or avoid contact with them on the street, and the preschool institution creates favourable conditions for communication between different children" (VI 3).

Two respondents stated that the answer to this question could not be unambiguous, because, on the one hand, communication of ordinary children with special needs enriches the life and social experience of all children, expands their understanding of different people. But at the same time, it slows down the acquisition of knowledge and skills in ordinary children. An ordinary child can develop at a faster rate than a child with inclusion (VI 4; VI 6).

As it was established at the first stage of the research, one of the conditions for readiness to work in inclusive groups is the level of professional training of educators.

Next, we offer typical judgments of educators on self-assessment of readiness to work in inclusive groups and an explanation of their own position:
"I assess my level of readiness to work in an inclusive institution as high. Thanks to the special pedagogical education of a speech therapist, I know how to organize work with inclusive children" (VI 1).

"My level of readiness to work in an inclusive institution can be assessed as sufficient. For many years (over 25 years) of pedagogical experience, we have already learned to work with preschoolers. However, there is a lack of professional experience (3 years) with inclusive children; there is insufficient knowledge about the peculiarities of the organization of children's lives in an inclusive group. Namely, how to unite ordinary children with special needs for joint activities. We know how to work with children with the norm, and what children with inclusion need is just beginning to understand. That is why we are now going through trial and error, but we are trying not to harm children" (VI 8).

"I have 30 years of teaching experience, including four years in an inclusive group. I assess my level of readiness to work with children with special educational needs as average because I lack knowledge. Although I received first secondary special, and then higher education, which allows me to work in groups of children of early and preschool age, to be a methodologist of a preschool institution. At one time, I graduated from a pedagogical institute, but now I am gaining knowledge on my own while observing the work of a speech pathologist, a behavioural therapist" (VI 3).

"I assess my level of readiness to work with children with special educational needs as average. I lack practical experience. It allows you to quickly navigate in any problem that arises" (VI 5)

"I assess my level of readiness to work in an inclusive institution below average. I lack knowledge of special pedagogy and psychology. I believe that teachers with special education should work in inclusive groups. Then they will have more knowledge about the peculiarities of working with inclusive children, more developed skills and abilities during the pedagogical practice in compensatory institutions" (VI 4).

Thus, assessing their professional opportunities to work in an inclusive group, most respondents talk about the lack of knowledge and experience to work in an inclusive group. Educators identify such necessary conditions for successful work as the availability of special education, the help of special educators, the possibility of continuous training and self-education, the conditions for gaining experience.

The in-depth research interview not only confirmed the barriers to inclusive education identified in the first phase of the study but also enriched the list. Most respondents 
reported overcrowded groups where the number of children exceeded the norm.

One of them said: "an inclusive group is attended by 31 children, three of them are children with special needs" (VI 6). Other spokes about her inclusive group, where among 22 children - two with Down syndrome and one with mental retardation (VI 8).

Educators consider the lack of adequate support from specialists to be a barrier to the introduction of inclusive education. One of the respondents emphasized: "The fact that inclusive education has been introduced is good, but it is bad that there is no proper support from specialists. First, it was necessary to train specialists, and then to open inclusive groups" (VI 4). Another respondent said emotionally: "In district inclusive resource centres, parents are told a lot about the benefits of inclusive groups. Therefore, most parents choose preschool education for their child in such groups, rather than in preschool institutions of compensatory type (for all children who need correction of physical or mental development). But after two months of the child's visit to the inclusive group, parents begin to wonder where the correctional classes that were promised to them in the inclusive resource centre. The question arises: why the preschool does not have the necessary specialists? The problem is also that children with different nosology can go to one inclusive group: with hearing impairments, with manifestations of autism. And each of them needs its own specialist. Unfortunately, the district inclusive resource centre only gives conclusions, and correctional work with the child is not carried out. Educators cannot help the child in a qualified way, because they are not specialists in special education, typhlo? pedagogy or speech therapy. On the contrary, we ask parents for advice on how to work with their child" (VI 6).

Respondents cited low wages as one of the barriers to inclusive education. For example, one of them commented on this as follows: "There are high requirements for an educator. He has a lot of work and a low salary. It also happens that after working with children, we have to attend seminars held after the shift. We also spend a lot of time searching for the necessary methodological literature for self-education. All this is an additional burden that is not paid for" (VI 6).

Respondents were generally positive about working with a tutor's assistant, although they mentioned issues that needed to be addressed, namely the appropriate division of responsibilities between the tutor and the assistant and trust in the partner. One respondent proudly reported a well-established collaboration with an assistant who has experience working in an inclusive group, and this helps to solve problems successfully (VI 8). "We have cooperation in working with an assistant educator. We do everything together for the benefit of children" (VI 2). Another respondent explained her self-esteem as follows: "I rate my readiness to work together with an assistant at 4 points. Because there were cases when the assistant provided inaccurate information about the child, and I could not prevent it. He feels subordinate in a certain way and therefore may not admit that something is wrong with a child" (VI 1). "I rate our work with an assistant educator at 4 points. We are not always able to distribute responsibilities on time. As a rule, the assistant deals with one of the most difficult children" (VI 3). "I evaluate my readiness to implement joint work with the assistant educator on 3 points. I deal more with ordinary children, and the assistant is responsible for organizing the pedagogical process with students with inclusion" (VI 4). "In our group, the functions of the assistant are to dress, undress, feed, put to bed children with special needs. Therefore, I assess my readiness to work together with the assistant on 2 points" (VI 5).

Respondents highly appreciated the importance of developing individual curricula. In their opinion, problems do not arise if a group of teachers participates in the planning of work: educator, assistant educator, director, educator-methodologist, psychologist, dermatologist. In their joint discussion, systematic, consistent and comprehensive planning of work is assumed (VI 1; VI 2; VI 3). If planning is transferred only to the educator and the assistant, they feel insecure, emphasizing that they do not have sufficient knowledge and skills, and therefore it is a barrier (VI 4; VI 8).

All respondents, without exception, understand the importance of organizing interaction between children, on which depends the psychological microclimate in an inclusive group and the desire of children to attend education. Thus, two respondents reported that they manage to organize positive interaction and communication between children with special needs and preschoolers who do not have such needs (VI 5; VI 7). Another interviewee spoke about pedagogical methods and techniques that she thought were more appropriate and effective: "We have no misunderstandings in the interaction between children. However, the educator must constantly monitor the situation in the group so that there are no signs of aggression on the part of the children. The educator must have different forms of communication and then teach all the children in the group" (VI 6).

"We are convinced that working in inclusive groups, and the main thing is not to be indifferent to the problems of children with special needs, to study their individual characteristics well and to understand why the child needs help in the first place. It is very difficult, but possible" (VI 1).

"In our group, there are children with mental disorders. That's why I have to constantly remind all the children not to hurry when we move in the column. Later, the children themselves suggested that the first to go in the column were children who sometimes lag behind. They will set the pace of movement along the corridor, on the stairs, at the 
entrance to the hall, and the whole group adjusts to this speed. This was facilitated by the favourable attitude of adults, the manifestations of their care for children with special needs that other children constantly saw and heard. So they wanted to imitate the behaviour of adults. Be that as it may, the children themselves took the initiative in creating a new group rule" (VI 3).

One of the educators said: "We have a barrier in the interaction between children and a boy with autism. The children are afraid of him. This is because the boy occasionally shows signs of uncontrolled aggression" (VI 4).

Cooperation with the family in many cases depends on the willingness of teachers to communicate openly and trustingly. When educators are set up to build trusting relationships, parents also show openness: they are ready to contact the staff of the preschool, to tell them about where the child receives additional educational services, correctional classes, why and how he is taught. One respondent said: "Today's parents of children with special needs are active enough and interested in giving their child a decent education so that they can develop, learn and be adequate in the society of ordinary children. Parents themselves study at various paid seminars, training, together with the child attend additional classes in the Development Centers. Then they share with educators, their impressions, show what work can still be done with children with special needs, what didactic and developmental material is better to use" (VI 1).

Another participant answered the question about her assessment of the quality of cooperation with parents: "We do not always manage to establish partnerships with parents, they do not always get in touch, they do not take into account the advice of specialists. The reason is that they often perceive the situation with the child as their own grief, which no one will help. These parents are quite closed, wary, do not trust teachers, believe that only they and no one else can help the child. They have a negative experience of society's attitude towards children with special needs. Therefore, they try to hide the existing problems. For me, the knowledge that parents share is important. For example, I learned about the counselling activities of a cognitive-behavioural therapist from a mother and received the necessary information from the Internet that allowed me to better understand the behaviour of children with mental disorders" (VI 3).

A similar opinion was expressed by another respondent: "Some families have a psychological barrier to admit that their child really has special needs" (P2); "Parents should trust the educators to whom they have brought a child with special needs. And give them more accurate and truthful information about the child, his individual abilities and skills. To adhere together with educators to the uniform requirements for the development, upbringing and education of a child with special needs. That there were no differences in requirements to the child from teachers and parents" (VI 6).

Respondents reported a sometimes-negative attitude of parents of ordinary children to children with special needs. They often believe that the intellectual potential of the latter is lower, and this can affect their children. Parents have a low awareness of inclusive education. For them, inclusion is perceived as a threat to the average child. Although seminars and round tables are held at the institution, this does not always work (VI 5; VI 8).

Thus, for most respondents, interaction with parents turned out to be quite a difficult problem. According to the respondents, most problems are related to the parents of children of both groups, who do not understand the benefits of inclusive groups, do not trust educators, do not provide accurate information about the child, do not contact, do not take into account expert advice, etc. At the same time, the child's problems and current needs often go unnoticed by educators of inclusive groups.

Educators who work with children with special needs, in their interviews, emphasized the importance of refresher courses, which are currently organized and conducted by various educational institutions. The problem may be only in the presence or absence of funds from teachers to pay for such an educational service (from 800 to 1500 hryvnia). Only a small number of educators are ready for this (only two educators have completed refresher courses at their own expense). Respondents noted that the Institute of Postgraduate Pedagogical Education in Kyiv should open special courses for educators who work or want to work in inclusive groups. These courses should consider not general but specific issues of organizing work with children with a certain nosology, to provide an opportunity to exchange views and experiences (VI 1; VI 4; VI 6).

Consultations of the director, educator-methodologist, psychologist of the preschool institution are more effective than other forms of methodical work carried out outside the preschool institution. Because they do not need to wait for the issue to be resolved. On the positive side, neither the principal, nor the educator-methodologist, nor the psychologist imposes his/her vision of the problem on the educators but help in understanding its possible solution. Yes, one of the respondents said "I get advice from the director and educator-methodologist of our institution on all the questions I have. If necessary, I have the opportunity to consult a psychologist. At all the methodological activities held in our preschool, we received a lot of useful advice on methods and techniques of working with children with special needs. At the last consultation, we were told how to introduce children to society so that they do not feel like outcasts. How to use sequence cards" (VI 2).

\section{Conclusions}

Thus, the results of the interviews with educators of 
preschool institutions showed that most of them are positive about working in inclusive groups, they see this as a benefit for children and for their professional and personal growth. However, they lack knowledge about the features of child support, lack of support from special educators, not worked out the mechanisms of interaction between the educator and the educator's assistant. They have difficulty in organizing the educational process in inclusive groups, often unable to cope with the behavioural problems of children with special needs.

The analysis of international experience in the organization of inclusive education and readiness of educators to work in inclusive classrooms, further practical research showed the common problems of different countries in the introduction of inclusive education and readiness of educators/teachers for such work.

Ukrainian educators/teachers have different visions and different attitudes to the idea of inclusive education; many of them are not ready for significant changes in their professional activities in the direction of inclusive education of children. Established norms and rules for the organization of the educational process in an educational institution where obedience is cultivated, external order, strict regulations prevent the positive acceptance of the inclusion of children with special needs, which may slightly change the process in the group. Educators with up to 5 years of work experience and educators who already have experience in such work are more inclined to work in inclusive groups. The latter confirms the thesis that the main factor in shaping the readiness of teachers to work in inclusive classrooms is preparedness for such work, in particular, possession of the necessary skills and pedagogical practices, equipment, compliance with the number of children in the classroom, support from colleagues and leadership.

\section{REFERENCES}

[1] Ketrish, E. V., \& Dorozhkin, E. M. (2016). Building of Projecting Competence among Future Teachers in the Conditions of Introduction of Inclusive Education. International Journal of Environmental and Science Education, 11(15), 8237-8251.

[2] Triukhan, O., Chumachenko, I., Zanko, O., Andrii, H., \& Formaniuk, V. (2020). Legal Guarantees for the Protection of the Labor Rights of Persons with Disabilities in Ukraine. J. Pol. \& L., 13, 164.

[3] Klyap, M., \& Klyap, M. (2016). Innovative directions of the higher education of Ukraine. Studia Universitatis „Vasile Goldis" Arad-Economics Series, 26(4), 54-66.

[4] Solovieva, I. L., Zherebjateva, C. A., Solovieva, O. A., \& Mironova, A. V. (2020, May). Characteristics of the Psychological and Pedagogical Support of Children with
Sensory Disabilities. In International Scientific Conference "Digitalization of Education: History, Trends and Prospects" (DETP 2020) (pp. 878-884). Atlantis Press.

[5] Chasnikova, O. V., Dubrovina, I. V., \& Zinchenko, O. M. (2020). ICT Concepts Development in Educational Theory and Practice since the Time of Independence of Ukraine.

[6] Pryima, S., Orlov, A., Anishchenko, O., \& Pozdnyakova-Kirbyateva, E. (2018). A study on educational needs of adults (on the example of Zaporizhzhia region residents).

[7] Talanchuk, I. (2015). Administrative and legal regulation of Ukraine on education for persons. Social welfare interdisciplinary approach, no 5(1), pp. 94-102

[8] Vinogradova, N., Syomina, M., \& Kokhan, S. (2020, January). Occupational Burnout of Educators Implementing Inclusive Education Programs in General Educational Institutions. In International Scientific and Practical Conference on Education, Health and Human Wellbeing (ICEDER 2019). Atlantis Press.

[9] Clavert, M. (2018). Academics' transformative learning at the interfaces of pedagogical and discipline-specific communities.

[10] Roose, I., Goossens, M., Vanderlinde, R., Vantieghem, W., \& Van Avermaet, P. (2018). Measuring professional vision of inclusive classrooms in secondary education through video-based comparative judgement: An expert study. Studies in Educational Evaluation, 56, 71-84.

[11] Anke de B., Sip J. P. \& Minnaert A. (2011). Regular primary schoolteachers' attitudes towards inclusive education: a review of the literature, International Journal of Inclusive Education, no 15(3), pp. 331-353. DOI: 10.1080/13603110 903030089

[12] Saloviita, T. (2018). Attitudes of Teachers Towards Inclusive Education in Finland, Scandinavian Journal of Educational Research. DOI: 10.1080/00313831.2018.15418 19

[13] Avramidis, E. \& Norwich, B. (2002). Teachers' attitudes towards integration. European Journal of Special Needs Education, no 17(2), pp.129-147. DOI: 10.1080/088562502 10129056).

[14] Gezer, M.S. \& Aksoy, V. (2019). Perceptions of Turkish preschool teachers' about their roles within the context of inclusive education. International Journal of Early Childhood Special Education, no 11(1), pp. 31-42. DOI: 10.20489/intjecse.583541 Retrieved from https://www.rese archgate.net/publication/334096430_Perceptions_of_Turkis h_Preschool_Teachers'_about_Their_Roles_within_the_Co ntext_of_Inclusive_Education

[15] Moberg, S., Muta, E., Korenaga, K., Kuorelahti, M. \& Savolainen, H. (2019). Struggling for inclusive education in Japan and Finland: teachers' attitudes towards inclusive education, European Journal of Special Needs Education. DOI: $10.1080 / 08856257.2019 .1615800$

[16] Leatherman1, J.M. \& Niemeyer, J.A. (2005). Teachers' Attitudes Toward Inclusion: Factors Influencing Classroom Practice, Journal of Early Childhood Teacher Education, no 26(1), pp. 23-36. DOI: 10.1080/10901020590918979 
[17] Fyssa, A., Vlachou, A. \& Avramidis, E. (2014). Early childhood teachers' understanding of inclusive education and associated practices: reflections from Greece, International Journal of Early Years Education, no 22(2), pp. 223-237. DOI: 10.1080/09669760.2014.909309

[18] Hasting, R.P. \& Oakford, S. (2003). Student Teachers' Attitudes Towards the Inclusion of Children with Special Needs Educational psychology (Dorchester-on-Thames. Prin), no 1(23), pp. 87-94.

[19] Forlin, C. (1995). 'Educators' beliefs about inclusive practices in Western Australia'. British Journal of Special Education, no 22, pp.179-185

[20] Purdue, K. (2009). Barriers to and Facilitators of Inclusion for Children with Disabilities in Early Childhood Education. Contemporary Issues in Early Childhood, no 2(10). Retrieved from www.wwwords.co.uk/CIEC

[21] Hyun, J.J. \& Peterson, C.A. (2003). Preservice teachers' attitude towards inclusion: Preschool and primary education programs, Journal of Preschool Pedagogical Education, no 24(3), pp. 171-179. DOI: 10.1080 / 1090102030240306

[22] Dorji, R., Bailey, J., Paterson, D. et al. (2019). Bhutanese teachers' attitudes towards inclusive education. International Journal of Inclusive Education, no 1(20). DOI: $10.1080 / 13603116.2018 .1563645$

[23] Weiss, S., Muckenthaler, M., Heimlich, U. et al. (2019). Teaching in inclusive schools. Do the demands of inclusive schools cause stress?

[24] Stephens, T. \& Braun, B. L. (1980). 'Measures of regular classroom teachers' attitudes toward handicapped children', Exceptional Children, no 46, pp. 292-294

[25] Zoniou-Sideri, A. \& Vlachou, A. (2006). Greek teachers' belief systems about disability and inclusive education. International Journal of Inclusive Education, no 10(4/5), pp.379-394

[26] Majoko, T. (2016). Inclusion in early childhood education: pre-service teachers voices, Early Child Development and Care, no 186(11), pp. 1859-1872. DOI: 10.1080/03004430. 2015.1137000

[27] Sharma, U., Forlin, C., Loreman, T., \& Earle, C. (2006). Pre-Service Teachers' Attitudes, Concerns and Sentiments about Inclusive Education: An International Comparison of Novice Pre-Service Teachers. International journal of special education, 21(2), 80-93.

[28] Shareefa, M. (2016). Institutional and teacher readiness for inclusive education in schools of Hithadhoo, Addu, Maldives: A study of the perceptions of teachers. International journal of scientific \& Technology research, 5(7), 6-14.

[29] Kemple, K. M., Hartle, L. C., Correa, V. I., \& Fox, L. (1994). Preparing teachers for inclusive education: The development of a unified teacher education program in early childhood and early childhood special education. Teacher Education and Special Education, 17(1), 38-51.

[30] Yukich, G. (2010). Boundary work in inclusive religious groups: Constructing identity at the New York Catholic Worker. Sociology of Religion, 71(2), 172-196.

[31] Engelbrecht, P. (2006). The implementation of inclusive education in South Africa after ten years of democracy. European journal of psychology of education, 21(3), 253.

[32] Yankovych, O., \& Prymakova, V. (2019). Preparation of teachers in Ukraine's postgraduate education institutions on organization of inclusive school education.

[33] Oluremi, F. D. (2015). Inclusive Education Setting in Southwestern Nigeria: Myth or Reality?. Universal Journal of Educational Research, 3(6), 368-374.

[34] Šmelová, E., Ludíková, L., Petrová, A., \& Souralová, E. (2016). The Teacher as a Significant Part of Inclusive Education in the Conditions of Czech Schools: Current Opinions of Czech Teachers about the Inclusive Form of Education. Universal Journal of Educational Research, 4(2), 326-334. 